\title{
DIVERGENT EMERGING MARKET ECONOMY RESPONSES TO GLOBAL AND DOMESTIC MONETARY POLICY SHOCKS
}

Woon Gyu Choi, Taesu Kang, Geun-Young Kim, and Byongju Lee

NO. 532

December 2017
ADB ECONOMICS WORKING PAPER SERIES 
ADB Economics Working Paper Series

\section{Divergent Emerging Market Economy Responses to Global and Domestic Monetary Policy Shocks}

Woon Gyu Choi, Taesu Kang, Geun-Young Kim, and Byongju Lee

No. 532 | December 2017
Woon Gyu Choi (wchoi@imf.org) is a senior economist at the Institute for Capacity Development, International Monetary Fund (IMF); Taesu Kang (tskang@bok.or.kr) is a senior economist at the Research Department, The Bank of Korea (BOK); Geun-Young Kim (kgy3104@bok.or.kr) is the head of Economic Activities Analysis Team at the Research Department, BOK; and Byongju Lee (brian.lee@bok.or.kr), the corresponding author, is an economist at the Economic Research Institute, BOK.

This paper was presented at the ADB-UNSW International Conference on Financial Cycles, Systemic Risk, Interconnectedness, and Policy Options for Resilience held in Sydney, in connection with the preparation of the theme chapter of the Asian Economic Integration Report 2017.

This paper is a revision of a previous work titled "US Monetary Policy Normalization and EME Policy Mix from a Global Liquidity Perspective." The authors are grateful to participants of the NBER East Asia Seminar on Economics in 2014 and above-mentioned conference in Sydney for helpful comments. Byongju Lee is grateful to the dedicated work of his research assistant Hyeonsang Jang. The views expressed herein are those of the authors and do not necessarily reflect the official views of BOK and the IMF. 
(C) 2017 Asian Development Bank

6 ADB Avenue, Mandaluyong City, 1550 Metro Manila, Philippines

Tel +632632 4444; Fax +6326362444

www.adb.org

Some rights reserved. Published in 2017

ISSN 2313-6537 (Print), 2313-6545 (electronic)

Publication Stock No. WPS179183-2

DOI: http://dx.doi.org/10.22617/WPS179183-2

The views expressed in this publication are those of the authors and do not necessarily reflect the views and policies of the Asian Development Bank (ADB) or its Board of Governors or the governments they represent.

ADB does not guarantee the accuracy of the data included in this publication and accepts no responsibility for any consequence of their use. The mention of specific companies or products of manufacturers does not imply that they are endorsed or recommended by ADB in preference to others of a similar nature that are not mentioned.

By making any designation of or reference to a particular territory or geographic area, or by using the term "country" in this document, $A D B$ does not intend to make any judgments as to the legal or other status of any territory or area.

This work is available under the Creative Commons Attribution 3.0 IGO license (CC BY 3.0 IGO)

https://creativecommons.org/licenses/by/3.0/igo/. By using the content of this publication, you agree to be bound by the terms of this license. For attribution, translations, adaptations, and permissions, please read the provisions and terms of use at https://www.adb.org/terms-use\#openaccess

This CC license does not apply to non-ADB copyright materials in this publication. If the material is attributed to another source, please contact the copyright owner or publisher of that source for permission to reproduce it. $A D B$ cannot be held liable for any claims that arise as a result of your use of the material.

Please contact pubsmarketing@adb.org if you have questions or comments with respect to content, or if you wish to obtain copyright permission for your intended use that does not fall within these terms, or for permission to use the ADB logo.

Notes:

In this publication, "\$” refers to US dollars.

ADB recognizes "Hong Kong" as Hong Kong, China and "Korea" as the Republic of Korea.

Corrigenda to ADB publications may be found at http://www.adb.org/publications/corrigenda. 


\section{CONTENTS}

TABLE AND FIGURES

ABSTRACT

$\begin{array}{ll}\text { I. INTRODUCTION } & 1\end{array}$

II. EMPIRICAL MODEL 2

III. EMERGING MARKET ECONOMY RESPONSES TO UNITED STATES AND DOMESTIC MONETARY TIGHTENING

A. Reactions in Growth, Inflation, and Policy 4

B. Effects on Components of Capital Flows 8

IV. DIVERGENT RESPONSES OF EMERGING MARKET ECONOMIES TO UNITED STATES MONETARY POLICY SHOCKS

A. Do Emerging Market Economy Responses Depend on Their Economic Fundamentals? 9

B. Does the Rate of Inflation Matter in Transmitting Policy Shocks?

C. Counterfactual Exercise: Mimicking Low-Inflation Economies 14

V. CONCLUSIONS

$\begin{array}{ll}\text { APPENDIX } & 17\end{array}$

$\begin{array}{ll}\text { REFERENCES } & 21\end{array}$ 


\section{TABLE AND FIGURES}

TABLE

Divergent Impacts of Global and Domestic Monetary Policy Shocks on EME Groups

\section{FIGURES}

$1 \quad$ EME Responses to a US Federal Funds Rate Hike 5

2 EME Responses to a Domestic Policy Rate Hike 7

3 EME Responses of Capital Inflows to Global and Domestic Monetary Policy Shocks 9

$4 \quad$ EME Fundamentals and Welfare-Relevant Measures after US Monetary Tightening 11

5 Responses of EME Groups to the US Federal Funds Rate Hike 13

6 Counterfactual Exercise of High-Inflation EMEs Taking the Shock-Absorbing Process of Low-Inflation EMEs

A.1 Fundamentals of Emerging Markets and Real GDP Growth and Consumer Price Inflation after US Monetary Tightening

A.2 Fundamentals of Emerging Markets and Nominal Appreciation and Capital Inflows after US Monetary Tightening 


\begin{abstract}
We assess the effect of the United States (US) and domestic monetary policies on emerging market economies (EMEs) using a panel factor-augmented vector autoregressive model. We find a US policy rate hike outstrips a tantamount hike in EME policy rates in its impacts on EMEs and discover that bond flows are more sensitive to interest rate differentials than are equity flows. Tighter global or EME-specific policy entails divergent responses of growth and inflation in EMEs: in particular, the output loss is greater in those EMEs with higher inflation. When US monetary policy tightens, bond and equity markets in EMEs are prone to outflows. Domestic policy alone is not enough to counteract the effects of global policy shocks on capital flows in EMEs.
\end{abstract}

Keywords: divergent responses, global liquidity, monetary transmission, panel factor-augmented VAR

JEL codes: F32, F42 


\section{INTRODUCTION}

Amid increased interconnectedness through global financial market integration in recent decades, waves of global liquidity have produced cross-border spillover effects. In the face of quantitative easing, tapering, and tightening, and the progress toward interest rate normalization driven by policy changes in advanced economies, policy makers and researchers attempt to assess possible quantitative effects on financial and real fronts, especially for emerging market economies (EMEs). In the past few years, central banks in emerging markets have followed keenly the evolving changes in the global financial landscapeas advanced economies unwind global liquidity-along with the corresponding repercussions on macrofinancial stability in their economies.

Against this backdrop, this paper focuses on how policy rates in the United States (US) affect macroeconomic outcomes and capital inflows in EMEs that are distinct from outcomes and flows that result when their domestic policy rates change. It sheds light on repercussions of looming global liquidity ebbs on policy responses and macrofinancial conditions in EMEs.

Specifically, we analyze how growth and inflation in EMEs react to a US policy rate hike. Considering that the US policy rate stayed at the zero lower bound for a significant time after the global financial crisis, we use a factor model with a large set of data, including price and quantity variables, to measure the policy stance even amid the zero lower bound policy rate and derive three liquidity drivers associated with global financial cycles. Following Choi et al. (2017), we identify the three drivers from a vector autoregressive (VAR) model with sign restrictions based on macrofinancial variables of advanced economies including the US federal funds rate and monetary base. We apply a factor-augmented vector autoregressive (FAVAR) model to EME panel data.

This approach allows us to control for the other elements of global liquidity and idiosyncratic characteristics of each EME. We look into the effects on growth, inflation, capital inflows, stock prices, exchange rates, current account, domestic policy rates, and foreign reserves. The empirical approach is also employed to gauge the effects of tighter domestic policy in EMEs.

Capital flows into EMEs are an important transmission channel of global liquidity, as examined by Morgan (2011); Rey (2015); Broner et al. (2013); Cerutti, Claessens, and Ratnovski (2014); Alberola, Erce, and Serena (2016); Kim and Shin (2016); Chari, Dilts-Stedman, and Lundblad (2017); and Cerutti, Claessens, and Rose (2017). We analyze four components of capital inflows: bond investments, equity investments, foreign direct investments, and other investments.

The second part of this paper explores how the divergent EMEs' sensitivities to global liquidity cycles are associated with their economic fundamentals. Studies such as Edwards (2010); Frankel, Schmukler, and Servén (2004); Kim and Yang (2009); and Valente (2009) have explored differences in region, industrial structure, or exchange rate regime to figure out the source of divergent impacts. In this study, we group data points by levels of variables such as inflation, real GDP growth, current accounts, or foreign reserves. We evaluate the welfare loss of each group from US monetary tightening and figure out the most potent fundamental that influences the welfare outcome of the external shock. We also carry out a counterfactual exercise to determine whether welfare gains would accrue if EMEs with vulnerable fundamentals adopted the domestic shock-absorbing structures of their more robust counterparts.

There are three key findings. First, the impact of a global interest rate hike on EMEs outstrips a domestic interest rate hike. In particular, a 1 percentage point increase of the US policy rate (translated 
into an unexpected shock to policy-driven global liquidity) reduces GDP growth of EMEs by 50 basis points over 3 years, while a 1 percentage point increase in the domestic policy rate of EMEs on average slows down their economies by 16 basis points. Second, all components of capital inflows to EMEs shrink in response to the US policy rate hike, but only bond investments by foreigners respond significantly to EMEs' own policy rate increases. Third, EMEs experiencing high inflation are more susceptible to a tightening in global liquidity than low-inflation EMEs in terms of their growth and inflation. A highinflation EME can achieve some welfare gains if it adopts a domestic economic structure conducive to keeping prices stable.

The next section of the paper presents the FAVAR model used to reach these conclusions, while subsequent sections illustrate the effects of US and domestic monetary tightening and investigate the sources of fragility of EMEs.

\section{EMPIRICAL MODEL}

To address the challenge of applying major countries' policy rates, close to the zero lower bound, as driving factors, Choi et al. (2017) distill multifaceted global liquidity into three drivers from both priceand quantity-based monetary and financial variables and incorporate them into a panel FAVAR model to investigate their effects on EMEs. Following the model set out in Choi et al. (2017), we use three forces, or momenta, of global liquidity: policy-driven liquidity, market-driven liquidity, and risk averseness.

The three global liquidity momenta, $F_{t}$, are retrieved from financial data $\left(X_{t}\right)$ of the five advanced economies (the US, Germany, France, Japan, and the United Kingdom) using a factor model with sign restrictions. For example, a decrease in the policy-driven liquidity momentum is set to decrease the US monetary base. Underlying financial time series used in retrieving factors are policy rates, domestic credit, international claims, lending rate spreads, government bond yields, monetary base, real interest rates, stock prices, and stock volatility - see Choi et al. (2017) for details of the metric of global liquidity and discussions.

Underlying data $\left(X_{t}\right)$ are explained by factors $\left(F_{t}\right)$ and their idiosyncratic disturbances $\left(u_{t}\right)$, of which the covariance is $\Psi$.

$$
X_{t}=\Lambda F_{t}+u_{t}
$$

Factors $F_{t}$ are assumed to be exogenous to EMEs in explaining macroeconomic and financial situation $Y_{t}$ as expressed in (2). Note that the factors have both contemporaneous and lagged effects on EMEs.

$$
Y_{t}=\sum_{i=1}^{k} A_{i} Y_{t-i}+\sum_{i=1}^{l} B_{i} F_{t-i+1}+\varepsilon_{t}
$$

\footnotetext{
1 Here are the dimensions of the matrices: $X_{t}, N \times M$ by $T ; \Lambda, N \times M$ by $3 ; F_{t}, 3$ by $T ; u_{t}, N \times M$ by $T ; \Psi, N \times M$ by $N \times M$. $N$ is the number of advanced economies and $M$ is the number of underlying variables. $T$ is the number of periods.
} 


$$
F_{t}=\sum_{i=1}^{m} C_{i} F_{t-i}+v_{t}
$$

The macrofinancial variables of EMEs in $Y_{t}$ comprise real GDP growth (RGDP), consumer price index (CPI) inflation, current account balance as percent of GDP (CA), stock price growth (SP), nominal effective exchange rate (NEER) growth, and capital inflows as percent of GDP (CF). Two policy variables, overnight call rates (OC) and foreign reserves as percent of GDP (FR), are also included. The EME panel comprises 19 countries: Argentina, Brazil, Bulgaria, Chile, Czech Republic, Hungary, India, Indonesia, Israel, the Republic of Korea, Malaysia, Mexico, the Philippines, Poland, Romania, the Russian Federation, South Africa, Thailand, and Turkey.

The sample period runs from the second quarter of 1995 to the third quarter of 2014. The source of EME data used are provided in the data appendix of Choi et al. (2017). Data for real GDP, CPI, capital inflows, foreign reserves, and current account are seasonally adjusted; and the trend component of overnight call rates is removed by the Hodrick-Prescott filter. Real GDP, inflation, exchange rates, and stock prices are in quarter-on-quarter growth; and capital inflows (and their components), current account, and foreign reserves are measured as percent of the 5-year average of annualized nominal GDP. Two lags are used for the endogenous variables and the contemporaneous and one-period-lag factors are included in equation (2). To recover the shock process $\left(v_{t}\right)$ in global liquidity momenta, an autoregressive structure with the lag order of one in equation (3) is chosen based on the Hannan and Quinn (1979) information criterion.

An increase in the US federal funds rate is applied in vector $X_{t}$ and in turn feeds into $F_{t}$. The accompanying changes in $F_{t}$ induce the dynamic responses of EMEs, which is expressed in equation (2). For the first step, we assume multivariate normality of $X_{t}$ and $F_{t}$, as follows:

$$
\left(\begin{array}{l}
X_{t} \\
F_{t}
\end{array}\right)=N\left[\left(\begin{array}{l}
0 \\
0
\end{array}\right),\left(\begin{array}{cc}
\Lambda^{\prime} \Lambda+\Psi & \Lambda^{\prime} \\
\Lambda & I
\end{array}\right)\right]
$$

The conditional distribution $X_{t}$ given $F_{t}$ is also given by

$$
F_{t} \mid X_{t} \sim N\left[\Lambda\left(\Lambda^{\prime} \Lambda+\Psi\right)^{-1} X_{t}, I-\Lambda\left(\Lambda^{\prime} \Lambda+\Psi\right)^{-1} \Lambda^{\prime}\right]
$$

Hence, the expected shock, given the value of $X_{t}$, is

$$
E\left(F_{t} \mid X_{t}\right)=\Lambda\left(\Lambda^{\prime} \Lambda+\Psi\right)^{-1} X_{t}
$$

While it is not unlikely that a change in the US policy rate accompanies changes in the marketdriven and risk averseness global liquidity factors, we concentrate on the effect of the policy-driven global liquidity factor, preserving the other two factors. Using the well-known formula of conditional expectations under the assumption of multivariate normal distribution, we obtain the expected value of the policy-driven factor, given that the two others are assumed to remain intact. We note, however, that the US policy rate change generally entails changes in each of the global liquidity factors, and it may 
result in greater impacts on EMEs because concomitant changes in market-driven and risk aversion global liquidity factors could add to the effect of the US policy rate change. ${ }^{2}$

We consider two scenarios of adjustment in $X_{t}$. The first supposes a 1 percentage point hike in the US federal funds rate; and the second scenario entails a 1 percentage point increase in the US real interest rate on top of the increased federal funds rate. The second scenario reflects the slow response of US inflation to monetary tightening, as observed in Romer and Romer (2004) and Christiano, Eichenbaum, and Evans (1999). The first scenario brings about a shock tantamount to $58 \%$ of the standard deviation of the policy-driven factor; and the shock of the second scenario corresponds to $87 \%$ of the standard deviation. We take the second scenario confluence of the real interest rate rise and policy rate hike as the baseline.

Since we derive factors from the financial and monetary data of five advanced economies, including the US, any combination of changes in underlying variables $X_{t}$ is at our disposal for scenario exercises. We deliberately turn off concomitant changes from other advanced economies in consideration of the growing divergence in macroeconomic situations and corresponding monetary stances among leading advanced economies. We nonetheless keep the normal transmission of US monetary policy on its own price level still intact after the global financial crisis. ${ }^{3}$

\section{EMERGING MARKET ECONOMY RESPONSES TO UNITED STATES AND DOMESTIC MONETARY TIGHTENING}

\section{A. Reactions in Growth, Inflation, and Policy}

The immediate impact of global liquidity withdrawal owing to the federal funds rate hike is a reversal in net capital flows, which in part suspend or reduce capital inflows. Our finding in the first row of Figure 1 (below) confirms this front-line impact and accompanying repercussions on exchange rates and stock prices. As the supply of liquidity from foreign sources shrinks in the domestic financial markets, it directly decreases aggregate demand as evidenced by weak output and sluggish CPI inflation. An International Monetary Fund (2013) study analyzes the impact of a US monetary shock on other countries. The results are largely consistent with ours, although its approach of measuring the impact of a US policy shock on output of other countries differs in several aspects such as the shock-receiving countries (EMEs versus EMEs and advanced economies), the measure of output (real GDP versus industrial production), and data frequency (quarterly versus monthly). ${ }^{4}$

As shown in the third row of Figure 1, domestic authorities' policy rate responses and foreign reserve adjustments are limited. The response of policy rates-about a 5 basis point rise for the 1 percentage point hike in the US policy rate-is lukewarm and weaker than in other studies such as Frankel, Schmukler, and Servén (2004); and Edwards (2010, 2015).

2 For example, Miranda-Agrippino and Rey (2015) explain 4\% to 17\% of the variation in the volatility index by shocks to the federal funds rate in a VAR analysis.

3 We do not take into account inflation pressures stemming from structural shifts (for example, perpetual shifts in productivity growth and demographics), ultimately altering real interest rates.

4 In contrast, the earlier work by Canova (2005) finds that GDP in Latin American countries rises within a year after the shock and inflation increases immediately following a tightening of monetary policy. Canova recovered the US macroeconomic and monetary shocks from a VAR model and fed them into a VAR model of individual Latin American countries. He rationalized this outcome because simultaneous increases in interest rates in Latin American countries boosted capital inflows. 


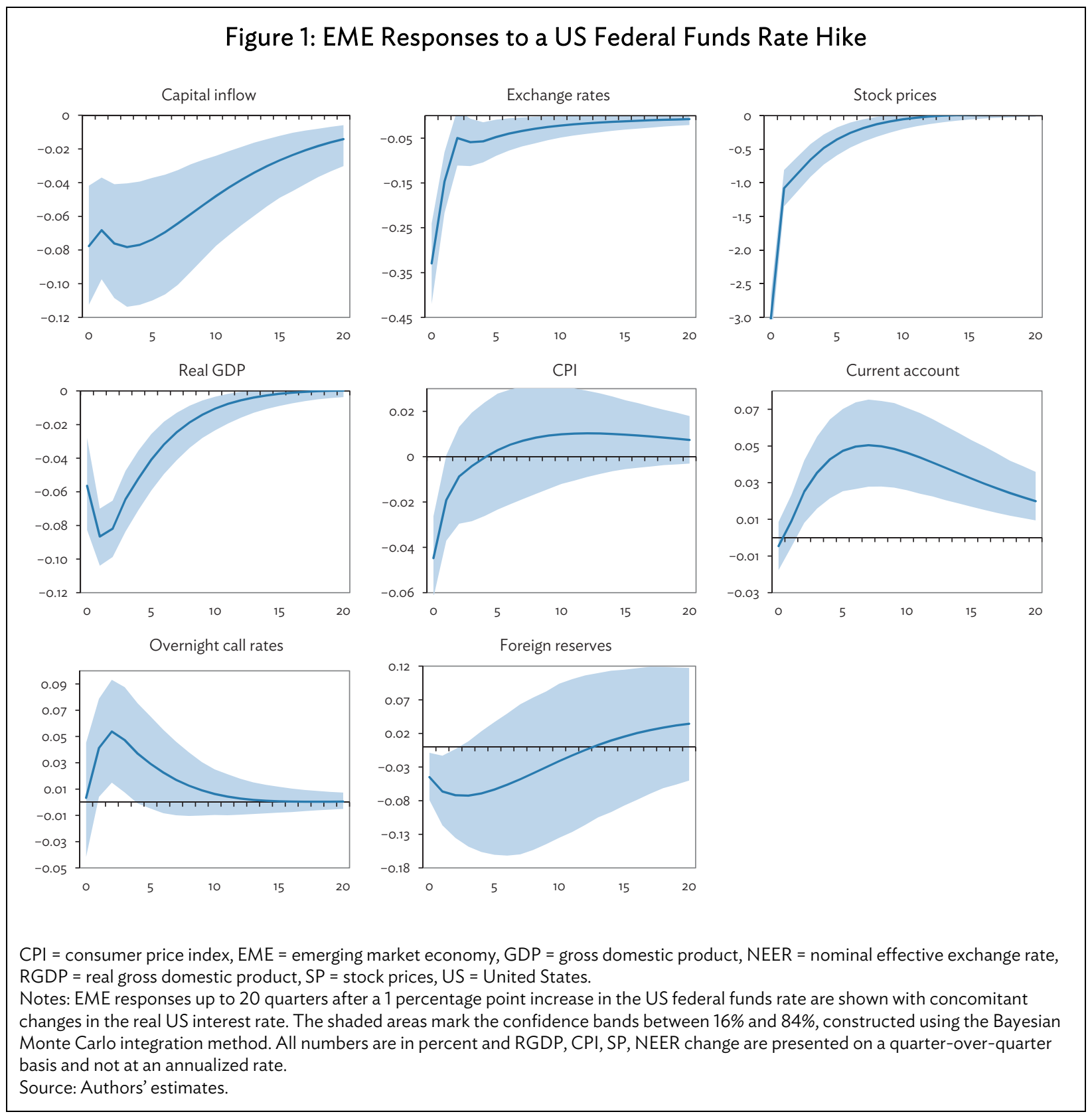

Frankel, Schmukler, and Servén (2004) argued for the full transmission of US interest rates to the rest of the world, especially to countries with fixed exchange rate regimes in the 1990s. In a similar vein, other studies have sought to identify the extent to which countries adjust their interest rates in response to changes in the US monetary policy stance. Valente (2009) finds that discretionary policy actions by the Federal Open Market Committee have smaller influence on interest rates in Hong Kong, China and Singapore than do policy changes based upon macroeconomic fundamentals. Edwards (2010) finds the degree of pass-through of US monetary policy to EMEs is higher in Latin America than in Asia, and attributes this to differences in the mobility of capital. Kim and Yang (2009) find that Asian countries under flexible regimes significantly adjust their interest rates in response to US monetary policy changes, while exchange rate responses are muted. They attribute this finding to fear of floating. Dées et al. (2010) find moderate policy spillovers from US tightening to 33 sample countries: the median 
spillover is 2 basis points against the US policy rate hike of 22 basis points. On the other hand, Lubik and Schorfheide (2006) report a limited transmission of US monetary shocks to Europe, based upon an estimated dynamic stochastic general equilibrium model.

A recent study by Edwards (2015) finds relatively strong spillovers of US monetary policy onto emerging markets in Asia and Latin America-33 to 74 basis point increases in the policy rates in EMEs. He uses data from 2000 up to 2008, during which US monetary tightening was more attributable to US inflation than the global business cycle. However, US policy after the global financial crisis of 2008 seems to have been influenced by concerns about a slow recovery in domestic output and jobs, and relatively fast recoveries in EMEs after the crisis may have loosened the links between the monetary stances of the US and EMEs. ${ }^{5}$

We use data from after the global financial crisis, while most studies on monetary spillovers focus on periods before it began, when the US federal funds rate was not constrained by a zero lower bound. Two developments may have stymied the contagion of monetary policy from the US to EMEs. Foremost is, of course, the federal funds rate at zero lower bound. Although the US policy rate remained there for 7 years, most EMEs reacted to global liquidity waves that resulted from the vigorous and unconventional monetary policy of the US. Second, most existing studies on monetary contagion take the US as the epicenter, and largely abstract the contribution of other advanced economies to the supply of global liquidity. The synchronization in the supply of global liquidity from advanced economies seen before the crisis is at odds with recent divergences in monetary policy among them. This work takes a conservative position in that the US contribution to the supply of global liquidity is narrowly put into the exercise, while the secondary global liquidity generated from other advanced economies is turned off.

The present empirical model involves measuring the effect of domestic policy rates in EMEs. The main difficulty in assessing this is in controlling for monetary and financial shocks from advanced economies. The three global liquidity momenta take the role of control variables. However, our empirical model does not have full links between advanced economies and EMEs, in the sense that it plays down a spill-back channel from EMEs to advanced economies for the benefit of tractability given our model complexity. We employ recursive restrictions to identify the domestic monetary shock, placing variables in order of: CPI inflation, real GDP, current account, capital inflows, foreign reserves, overnight call rates, stock prices, and NEER. We place slow-moving real sector variables in front of variables reflecting financial flows. We assume that monetary policy makers in EMEs set their policy rates in response to innovations in real sector and financial flow data. Finally, we allow asset prices and NEER to react to domestic monetary shocks. We find that it is essential to have the aforementioned sequence over the groups of variables - such as real sector, financial flows, policy measures, and asset prices - to obtain reasonable responses but that any change in sequence within each group has little impact on the results.

Figure 2 depicts impulse responses to a 1 percentage point increase in the domestic policy rate of EMEs, along with the responses to the US policy rate hike for comparison. Domestic monetary tightening triggers initially moderate capital inflows, which are followed by a reversal with a lag, and domestic currency appreciations in two quarters with lower inflation and a current account surplus. Stock prices drop initially but quickly rebound. Responses of output growth, inflation, and the current account at their peaks are much less to the domestic policy rate hike than to the US policy rate hike.

5 While Edwards (2015) deals with a long-run policy contagion from the US to some EMEs, our study focuses on the dynamic responses of EMEs to global liquidity shocks driven by G5 monetary policy. For this purpose, we draw changes in the US policy rate, controlling for US real GDP growth and inflation of producer prices. Edwards' estimation focuses on the longrun contagion, employing an error correction model, while we estimate short-term spillovers based upon the VAR approach. 
Although output growth and the current account show similar response patterns across the two exercises, inflation exhibits different responses. Domestic policy tightening brings about a sluggish reaction in prices, consistent with earlier findings on the effect of US monetary shocks on inflation, as in Romer and Romer (2004) and Christiano, Eichenbaum, and Evans (1999), whereas US policy tightening entails an immediate fall in inflation in EMEs. These contrasting reactions may be attributable to different patterns in pricing. In the face of global liquidity tightening, importers can more readily adjust their prices, anticipating the strategic responses of domestic competitors and foreign suppliers to lower global demand. In contrast, tighter domestic policy leads to declines in domestic demand, and tends to reduce local prices. Another explanation is that global liquidity tightening may exert downward pressures on energy and commodity prices, which are heavily influenced by global demand and largely priced in US dollars, whereas tighter domestic policy affects the domestic prices of items priced in local currencies.

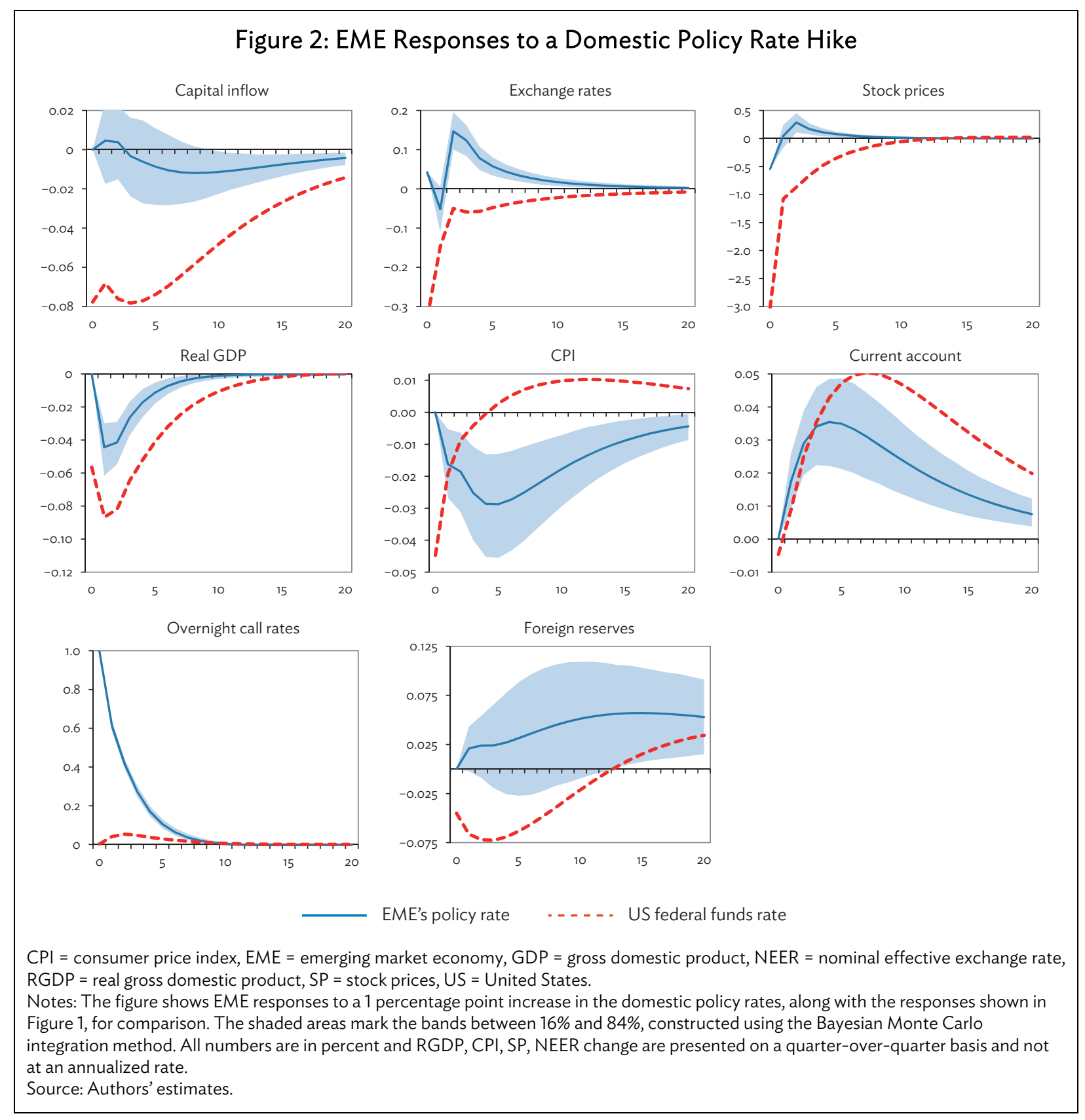


The responses of output growth and inflation in EMEs are largely consistent with findings from estimated New Keynesian open economy models such as Adolfson et al. (2007 and 2008) except for their timing. In our study, output immediately declines after domestic and US monetary tightening, but inflation reacts more slowly to domestic monetary shocks. Our finding that output growth responses precede inflation responses is similar to major studies based on US data (for example, Christiano Eichenbaum, and Evans 1999 and 2005).

EMEs are found to absorb part of incoming investments in their foreign reserves after domestic monetary tightening. This policy move is likely to limit the effect of the policy rate lift to some degree, by curbing domestic currency appreciation. Policy makers may choose this course of action to moderate the impact of hot money flows on inflation, in part through sterilized intervention, which results in foreign reserve accumulation and dampened responses in exchange rates. Alberola, Erce, and Serena (2016) in their panel analysis find that foreign reserves in EMEs have stabilizing effects on capital inflows during global financial turmoil, and report a significant interaction effect of the spread on the J.P. Morgan Emerging Markets Bond Index Plus (EMBI+) and international reserves, which moderates the first-order effect of the spread by reducing capital inflows to EMEs.

\section{B. Effects on Components of Capital Flows}

The previous section highlighted that global liquidity shrinkage causes overall outflows of foreign investments from EMEs. The International Monetary Fund categorizes capital flows into portfolio investments, direct investments, and other investments. Portfolio investments are divided further into bond investments and equity investments. Using the data, we look into whether the withdrawal of global liquidity has diverse effects across different categories of capital inflows to EMEs.

In response to tighter US monetary policy, all categories of capital inflows weaken substantively, but to different degrees (see the dotted lines in Figure 3). ${ }^{6}$ The most significant change is in foreigners' investments in domestic bonds, while equity inflows are only marginally affected. Direct investments by foreigners increase initially but soon reverse to significantly negative figures.

The solid lines in the figure depict how a domestic policy rate hike affects foreign investments in EMEs. Tightening domestic policy tends to impact capital flows less than tightening US policy, and is significant only for bond inflows, suggesting that adjusting policy rates in EMEs to handle capital flows could have limited effect.

6 Broner et al. (2013) examine the impact of banking, currency, and debt crises on capital flow components. They find declines in capital inflows during crises across all the components for upper-middle-income and lower-middle-income countries. 
Figure 3: EME Responses of Capital Inflows to Global and Domestic Monetary Policy Shocks
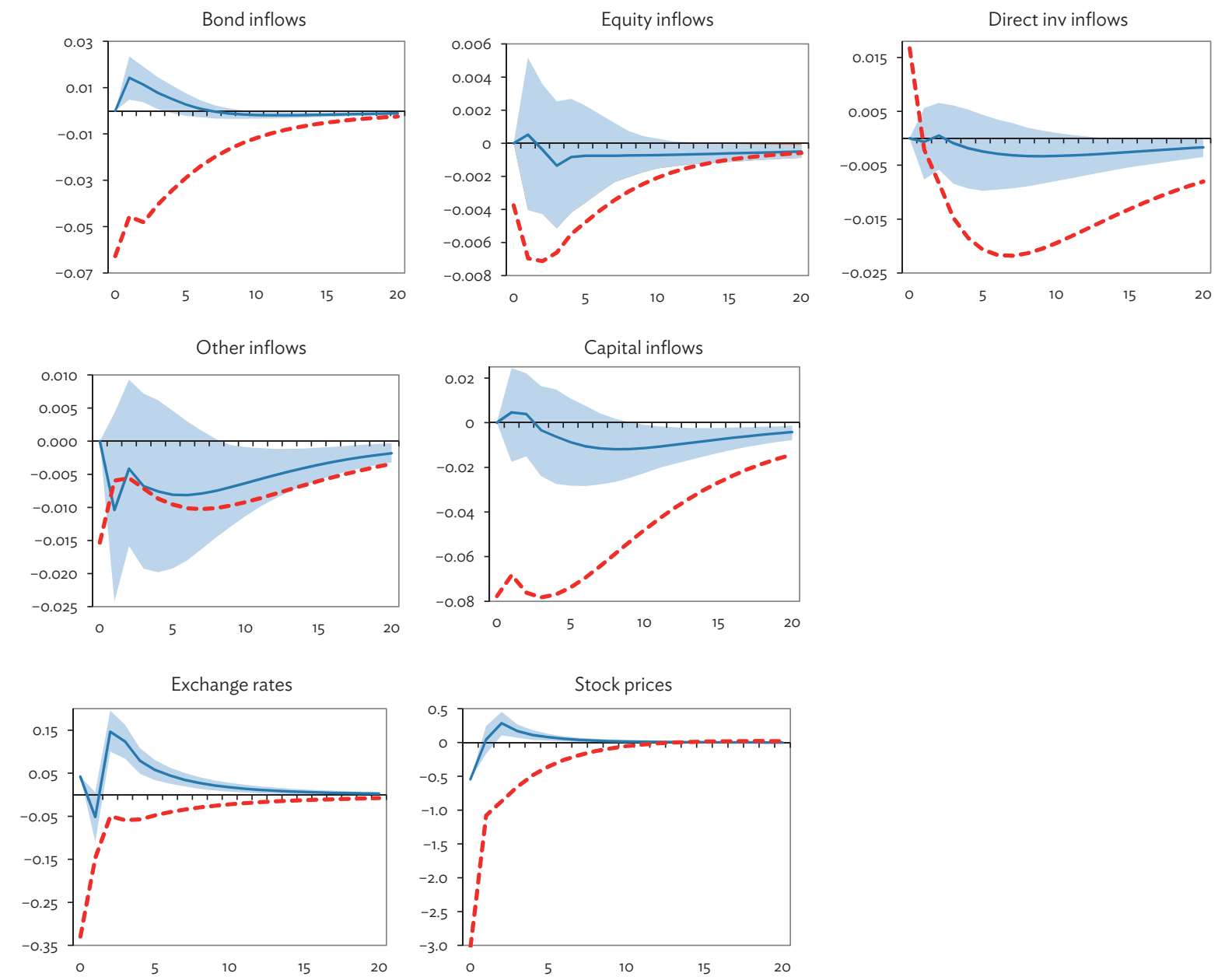

EME's policy rate : =- - - - US federal funds rate

$\mathrm{CPI}=$ consumer price index, $\mathrm{EME}=$ emerging market economy, inv = investment, NEER = nominal effective exchange rate, $\mathrm{RGDP}=$ real gross domestic product, $\mathrm{SP}=$ stock prices, US = United States.

Notes: Capital inflows to EMEs are shown up to 20 quarters after a 1 percentage point increase of the US federal funds rate (dotted line) and the same increase in the domestic policy rate (solid line). The shaded areas mark the bands between $16 \%$ and $84 \%$ for the domestic policy rate increase, constructed using the Bayesian Monte Carlo integration method. All numbers are in percent and RGDP, CPI, SP, NEER change are presented on a quarter-over-quarter basis and not at an annualized rate.

Source: Authors' estimates.

\section{DIVERGENT RESPONSES OF EMERGING MARKET ECONOMIES TO UNITED STATES MONETARY POLICY SHOCKS}

\section{A. Do Emerging Market Economy Responses Depend on Their Economic Fundamentals?}

In the previous section, we discovered that the withdrawal of global liquidity causes changes in output growth and inflation in EMEs. Welfare consequences of this may be different across countries. We look into the factors behind the differences. There are a few welfare approximations in terms of key macroeconomic variables, basically extending the approximation for a closed economy proposed by 
Woodford (2003). These are usually called loss functions, which are deemed as the objective function of policy authorities. For an open economy, Corsetti, Dedola, and Leduc (2010) derive approximations that apply to two-country models with various sets of economic structure. A standard approximation for a closed economy comprises the output gap and inflation. Approximations for an open economy could be augmented, with additional terms being inflation of import prices, terms of trade, deviations from the law of one price or deviations from exchange rates under perfect risk-sharing conditions, depending on assumptions on economic structure regarding financial market completeness and how import prices are set. We consider four variables to measure the welfare consequences of global liquidity withdrawal: real GDP growth, CPI inflation, exchange rate changes, and capital inflows. We include capital inflows in light of escalating concerns about capital flows in open economies and the necessity for capital flow management to gain monetary independence, notably as in Farhi and Werning (2014). We measure the deviation of each variable from the steady state for a 3-year period. ${ }^{7}$

We employ a grouping approach similar to Lustig and Verdelhan (2007). ${ }^{8}$ An alternative method to investigate the link between country characteristics and certain statistical outcomes is regressing an outcome on country characteristics, as in Miniane and Rogers (2007). A typical approach is running country-level VARs with limited lags and variables, obtaining a statistical outcome such as impulse responses and finally regressing the outcome on the variables of country characteristics. This approach, however, has to account for three issues: (i) observation inaccuracy owing to limited degrees of freedom; (ii) sample uncertainty in the second-stage regression owing to treating the outcome from the firststage analysis as a direct observation; ${ }^{9}$ and (iii) evolving country characteristics over time. The grouping method we use is free of these issues.

We divide 19 EMEs per period into four groups according to their prior characteristics. For example, we split 19 EMEs into four groups for the first quarter of 2001 according to their average CPI inflation from 1998 to 2000 . We do the same partitioning exercise with respect to other fundamentals such as output growth, exchange rate growth, the current account balance, foreign reserve ratio, stock price growth, and the capital flow ratio. Among the four groups for each indicator, the first group has countries with the lowest values. We form a panel from each group and apply the panel FAVAR model, finally measuring a loss function value for each group against the global liquidity shock. Figure 4 reports the most informative combinations among the exercises, and Figures A.1 and A.2 have the exhaustive sets from the exercise.

We find that CPI inflation has discernable welfare consequences with respect to real growth, $\mathrm{CPI}$ inflation, and the exchange rate, from the first column of Figure 4. Countries with high inflation in the previous 3 years are likely to experience more drastic output loss, even higher inflation, and larger depreciations than their moderately inflationary counterparts. The most inflationary group experiences a severe real depreciation against global liquidity withdrawal while the least inflationary group experiences moderate real appreciation due to the deflationary effect of liquidity loss and stable exchange rate against the shock.

7 This method of measuring deviation does not see exactly eye-to-eye on the measurement of the loss function but keeps information on the direction of responses and facilitates comparison with other studies.

8 Lustig and Verdelhan (2007) form portfolios so that each one includes a group of government bonds with similar interest rates where bonds are dynamically assigned to each portfolio. Thus, the government bonds of a single country may over time be included to different portfolios. The behavior of low- or high-yield currencies can be directly analyzed through these portfolios.

9 Miniane et al. (2007) mitigate the second issue by resampling the outcome from the distribution derived from the firststage VAR. 
Figure 4: EME Fundamentals and Welfare-Relevant Measures after US Monetary Tightening
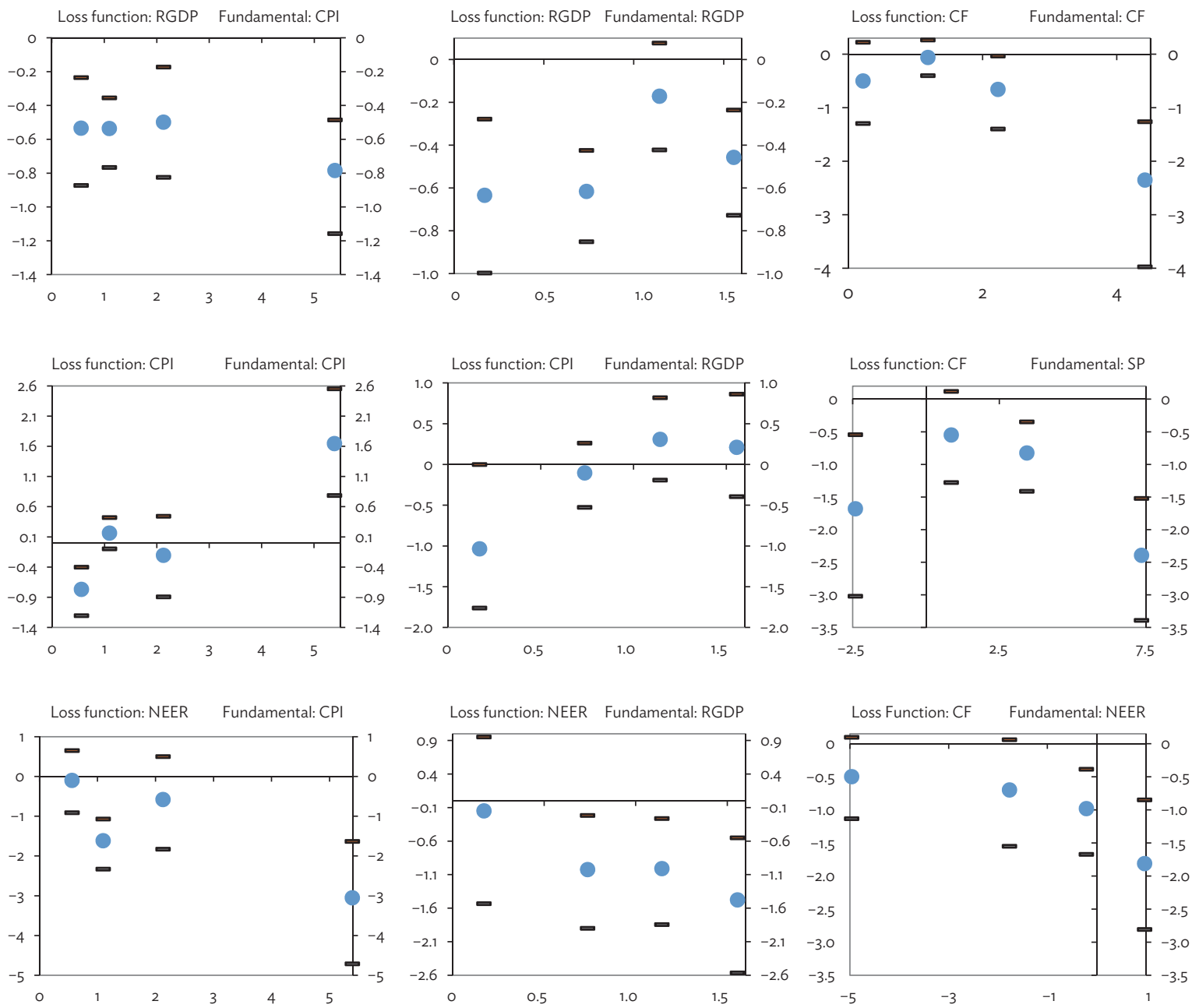

$\mathrm{CF}=$ capital inflows, $\mathrm{CPI}=$ consumer price index, $\mathrm{EME}=$ emerging market economy, $\mathrm{NEER}=$ nominal effective exchange rate, $\mathrm{RGDP}=$ real gross domestic product, $\mathrm{SP}=$ stock price, $\mathrm{US}=$ United States.

Notes: Points in each panel depict the relationship between a measure of fundamentals and a measure of the loss function. In each panel, the $\mathrm{x}$-axis stands for the 3-year average of a fundamental variable and the $y$-axis for the 3-year accumulation of the impulse response after US monetary tightening. All numbers are in percent and RGDP, CPI, SP, NEER change are presented on a quarter-over-quarter basis and not at an annualized rate. Bars above and below dots mark the bands between $16 \%$ and $84 \%$. Source: Authors' estimates.

Real GDP growth rates of EMEs in our samples are more evenly distributed than CPI inflation, as observed by the horizontal distance of points in the first and second column of the figure. A similar pattern of effects on real exchange rates is observed in groups partitioned by real growth rates. Countries that have grown faster than other EMEs will experience more real depreciation as shown in the second column of the figure. The loss of growth due to US monetary tightening is least severe for the group with the second-highest growth performance before the shock. The nonlinear pattern shown here may suggest that extremely high growth of a particular emerging market country may build up vulnerability to external risk.

The third column of the figure pertains to capital inflow responses to tighter US monetary policy. Countries that experienced larger capital inflows, significant gains in stock values, and relative 
strengthening of the currency before the shock are prone to see capital inflow reductions afterward. Using country-panel regressions, Broner et al. (2013) find evidence of retrenchment in capital inflows during the 3 years following a country-specific shock in lower- and upper-middle-income countries. Our finding here suggests that retrenchment in capital inflows after a US interest rate hike depends on the magnitude of inflows before the shock. ${ }^{10}$

We do not find a clear dependence of capital flow responses to tighter US monetary policy on foreign reserves (see Figure A2 in Appendix). Alberola, Erce, and Serena (2016) find that the magnitude of a decrease in capital inflows into EMEs due to global financial stress (measured by the Global EMBI+ spread) is small for countries with moderate foreign reserves (as fractions of international liabilities) and large for countries with either low or high foreign reserves. Policy authorities can build up foreign reserves to temper a country's vulnerability to sudden stops in capital flows. If foreign reserves are partially effective in curbing sudden stops in capital flows, the nonlinear pattern, as in the aforementioned study, is not necessarily inconsistent with the absence of a clear link between foreign reserves and reduced capital inflows due to global tightening.

\section{B. Does the Rate of Inflation Matter in Transmitting Policy Shocks?}

EME responses that result from the cross-border diversity of inflation produce different welfare implications. Since the rate of CPI inflation offers a clear demarcation of macroeconomic management among EME countries, we divide 19 EMEs into two groups: high-inflation and low-inflation groups." Countries in the high-inflation group saw on average a 14 percentage point annual increase in consumer prices over the sample period, while the low-inflation group experienced average inflation of only $4 \%$.

Figure 5 shows that high-inflation countries are more susceptible to a 1 percentage point hike in the US federal funds rate in their capital flows, policy rates, and consequently foreign reserves, output growth, and inflation. The welfare consequences are in part affected by domestic policy responses, especially changes in policy rates. High-inflation EMEs raise their policy rates in response to tighter US monetary policy in an effort to retain capital inflows or prevent capital outflows, consistent with the argument for policy spillovers. Interestingly, low-inflation EMEs reduce their policy rates after the initial rise, possibly conducive to shoring up stock prices and boosting aggregate demand. Despite positive responses in domestic policy rates, capital inflows do not have favorable effects in the high-inflation group.

10 The previous inflows of foreign capital are found to affect the magnitude of foreign investment reversal in response to a US interest rate hike but have little impact on growth and inflation. This finding is odd, given the concern that financial openness may be related to external vulnerability. There are two possible explanations. First, financial openness is an endogenous outcome of an economy rather than exogenously determined institutions. In an economy capable of managing capital inflows while gaining benefit from them, policy makers are more likely to initiate or accelerate financial liberation. Second, our measure is about the flows of capital rather than stock, and the financial openness of a certain country is better proxied by the stock of inbound investments.

11 The high-inflation group comprises Argentina, Bulgaria, Hungary, India, Indonesia, Mexico, Romania, the Russian Federation, and Turkey. The low-inflation group includes the rest of the sample countries except for Brazil, which is at the midpoint among EMEs in terms of CPI inflation. 


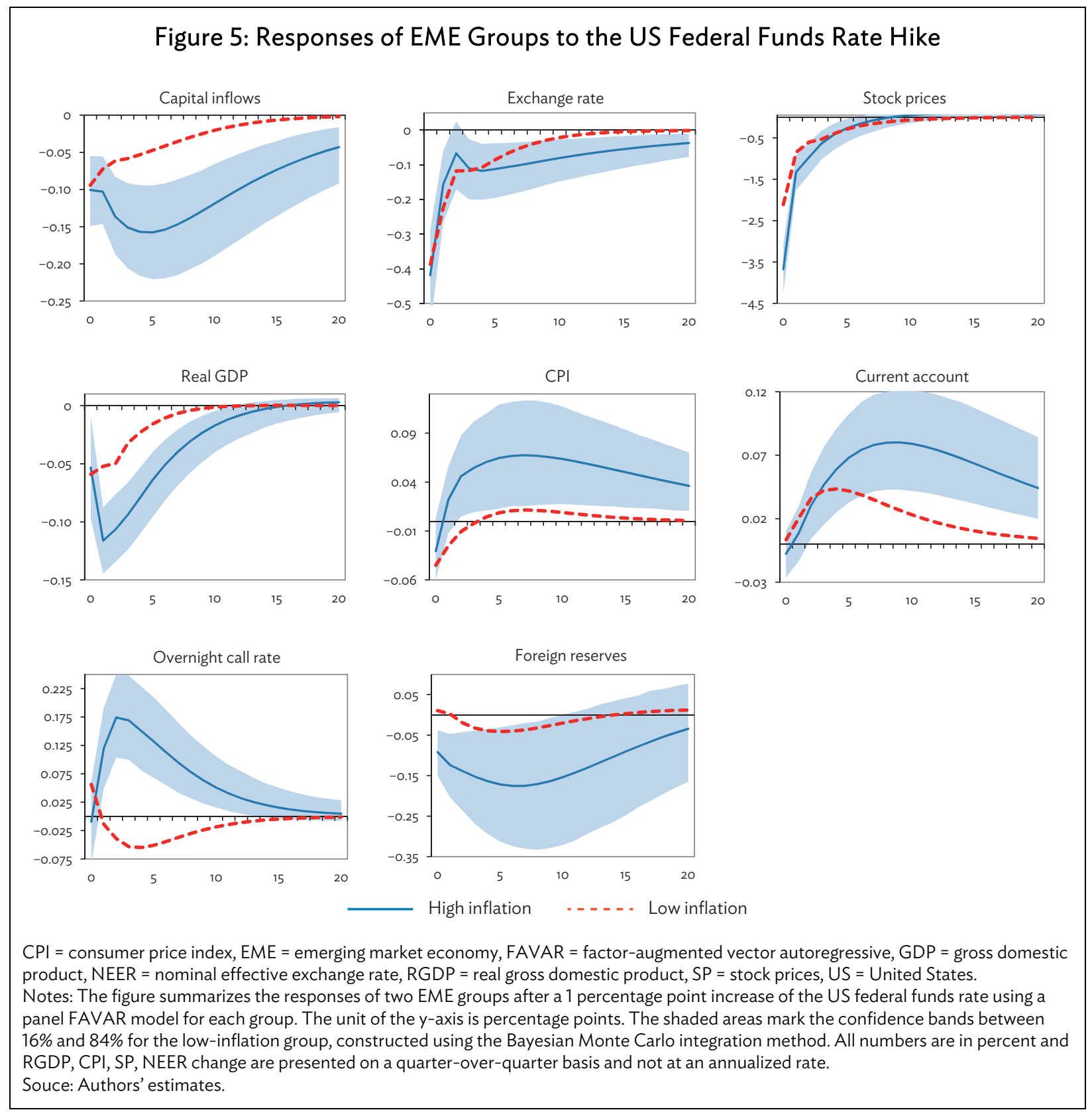

In terms of output growth and inflation, low-inflation EMEs can better absorb the shock than high-inflation EMEs (see table on page 14). Exchange rate and stock prices exhibit little quantitative differences. Real depreciation in the high-inflation group exceeds that in the low-inflation group; inflation in the former accelerates at a much greater magnitude after the first period than it does in the latter group while their currencies depreciate in similar magnitudes in later periods. As a result, countries in the high-inflation group have more advantageous conditions for external trade, benefiting their current account balances.

On the basis of the welfare measures used in the previous exercise, the high-inflation group loses more output than the low-inflation group. After US monetary tightening, the high-inflation group would have more pronounced price responses with higher inflation than the low-inflation one would as implied 
by New Keynesian sticky price models. All the welfare-relevant measures indicate that the high-inflation group fares much worse than the low-inflation group.

\section{Divergent Impacts of Global and Domestic Monetary Policy Shocks on EME Groups}

\begin{tabular}{llcccc}
\hline & & All & $\begin{array}{c}\text { High Inflation } \\
(\mathrm{H})\end{array}$ & $\begin{array}{c}\text { Low Inflation } \\
(\mathrm{L})\end{array}$ & $\begin{array}{c}\text { Difference } \\
(\mathrm{H}-\mathrm{L})\end{array}$ \\
\hline Global & Real GDP & -0.49 & -0.69 & -0.26 & -0.43 \\
liquidity & $\mathrm{HPI}$ & -0.02 & 0.61 & -0.01 & 0.62 \\
& Current account & 0.44 & 0.67 & 0.36 & 0.31 \\
& Exchange rates & -0.33 & -0.42 & -0.39 & -0.03 \\
& Overnight call rates & 0.05 & 0.17 & 0.06 & 0.12 \\
& Foreign reserves & -0.60 & -1.82 & -0.29 & -1.54 \\
& & & & & \\
Domestic & & & -0.17 & -0.21 & 0.04 \\
liquidity & Real GDP & -0.16 & -0.13 & -0.62 & 0.49 \\
& CPI & -0.26 & 0.24 & 0.74 & -0.50 \\
& Current account & 0.33 & 0.10 & 0.33 & -0.23 \\
& Exchange rates & 0.15 & -0.12 & 1.88 & -2.00 \\
\hline
\end{tabular}

$\mathrm{CPI}=$ consumer price index, $\mathrm{EME}=$ emerging market economy, GDP = gross domestic product, US = United States.

Notes: The table summarizes impulse responses of EMEs to a 1 percentage point increase in the US (global) policy rate and in domestic policy rates. Real GDP and CPI represent cumulative responses of output growth and CPI inflation, in percetange points, to the corresponding shock. Current account and foreign reserves represent cummulative responses of account balance and foreign reserves (both as percentages of nominal GDP) for 3 years to the corresponding shock. The exchange rate and overnight call rate are measured by the largest response to the corresponding shock during the first 3 years, again with both in percentage points.

Source: Authors' estimates.

\section{Counterfactual Exercise: Mimicking Low-Inflation Economies}

Broadly speaking, the divergent responses of the two EME groups can be attributed to EMEs having different immediate reactions to a shock and the absorbing processes after it hits. What would be the possible causes of such divergent responses? We attempt to answer the question whether the distinction comes from exogenous factors to EMEs or the domestic structure of their economies by employing a method used by Stock and Watson (2003). Specifically, we replace the estimate of A in equation (2) of the high-inflation group with the corresponding estimate of the low-inflation group. The counterfactual and original responses of the high-inflation group are collated in Figure 6. The dashed line of each panel shows how high-inflation group countries would absorb the shock if they had domestic economic structures that resembled the low-inflation group. Note that a global liquidity shock may have diverse initial impacts on the two groups, which are implied by the estimate of $B$ in equation (2).

As shown in Figure 6, gains to the high-inflation group from mimicking the low-inflation group dynamics are limited to fewer capital outflows, smaller foreign reserve drains, less inflation, and less currency depreciation. Lack of protection against the shock to output growth implies that immediate policy changes and other quick responses, for example through efforts to make the financial infrastructure more resilient, would be of first-order importance.

Noticeably, policy makers in high-inflation groups would not alter their reactions to changes in policy rates much over time even if they were to have the same economic structure as the low-inflation group-which is implied by the comparison between Figures 5 and 6 . Improvement in inflation 
responses, despite a marginal deterioration to output growth, may nonetheless suggest that the adoption of the domestic economic structure of the low-inflation group would improve welfare outcomes in the high-inflation group if inflation is given enough weight in their welfare metrics. ${ }^{12}$

\section{Figure 6: Counterfactual Exercise of High-Inflation EMEs Taking the Shock-Absorbing Process of Low-Inflation EMEs}
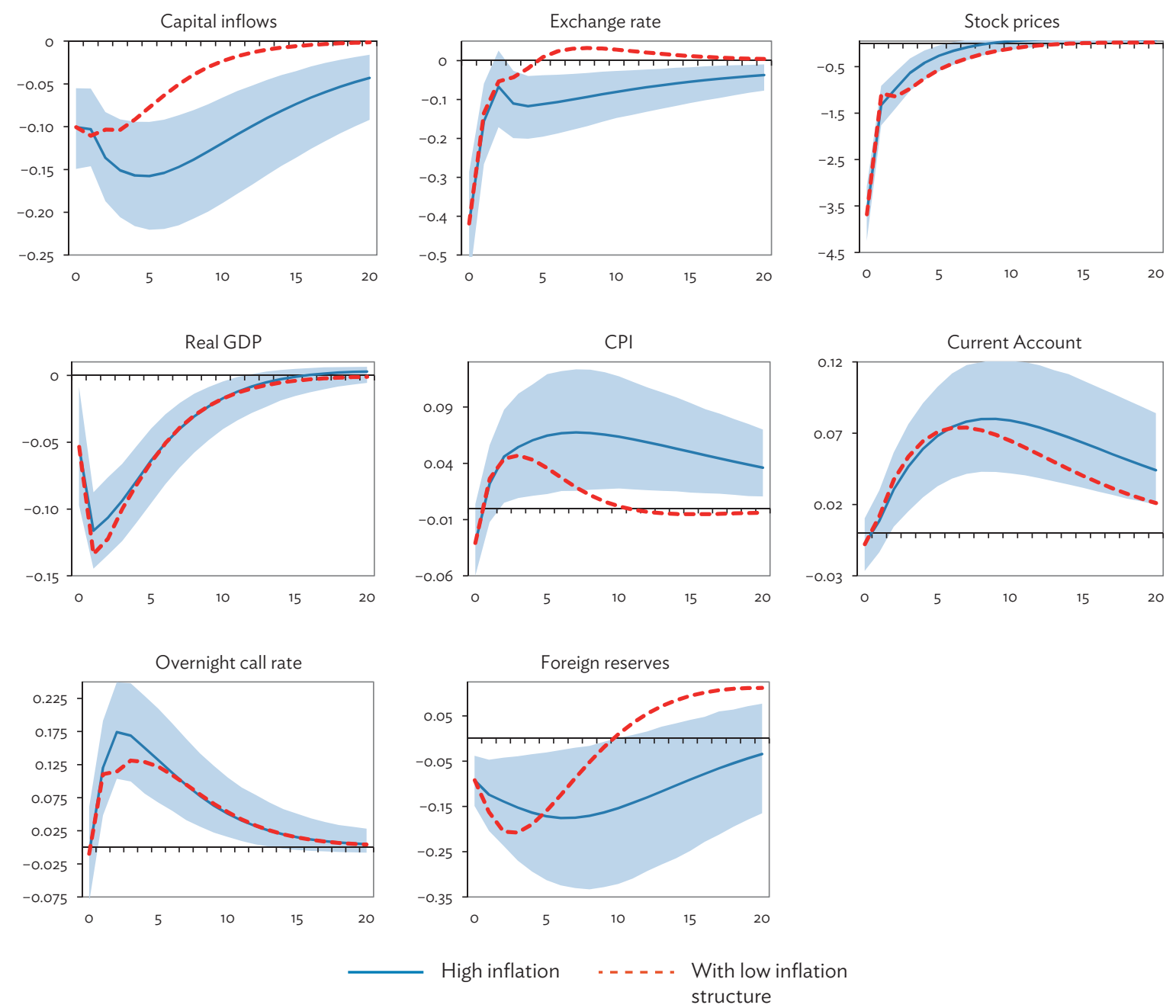

$\mathrm{CPI}=$ consumer price index, $\mathrm{EMEs}=$ emerging market economies, $\mathrm{GDP}=$ gross domestic product

Notes: The figure summarizes a counterfactual exercise by which the high-inflation group takes the shock-absorbing process of the lowinflation group in terms of the dynamic structure of lagged endogenous variables. Shaded areas around the solid lines mark the confidence bands between $16 \%$ and $84 \%$ of the high-inflation group. The unit of the $y$-axis is percentage points.

Source: Authors' estimates.

12 Apart from welfare gains from the improved responses of capital inflows and exchange rates, the gain from moderate inflation may outweigh the loss from output growth. Of course, this argument depends on the weights placed on inflation and output gap in the loss function. For an open economy, Woodford (2003) makes the relative weights between output gap and inflation the same as for a closed economy, although inflation in the loss function usually stands for inflation of domestic goods (Corsetti, Dedola, and Leduc 2010). A typical calibration of parameters results in a low weight on the output gap. Even if we use a higher weight on the output gap, as argued by Debortoli et al. (2015), the counterfactual outcome is still preferable to the original outcome. 


\section{CONCLUSIONS}

This paper investigates EME responses to monetary policy in the US and EMEs and attempts to link the drivers of the divergent responses seen to the fundamentals of EMEs. The analysis employs a FAVAR model to examine panel data from 19 EMEs, covering the second quarter of 1995 to the third quarter of 2014. A 1 percentage point increase in the US policy rate is found to reduce output growth in EMEs on average by a half percentage point. The impact of an increase in the US policy rate moreover outstrips a proportional domestic interest rate hike in the EMEs in this study. Of the EME capital markets, bond markets are most significantly affected by US monetary policy. While a US interest rate hike impacts all components of capital inflows to EMEs, only bond investments by foreigners are hurt significantly when interest rates rise in EMEs. Also, high-inflation EMEs are more susceptible to the US policy rate hike than low-inflation EMEs.

These findings allow some implications for EME monetary policy to be pinpointed. First, in managing capital flows, domestic monetary policy may not be effective enough to counteract global monetary policy shocks. Second, in the face of higher global policy rates, EMEs show divergent policy responses and their macro financial responses differ too, depending on their economic fundamentals. Lastly, EMEs with strong fundamentals have some room to apply independent monetary policy for macroeconomic stabilization during the course of normalization in global interest rates. 


\section{APPENDIX}

Figure A.1: Fundamentals of Emerging Markets and Real GDP Growth and Consumer Price Inflation after US Monetary Tightening
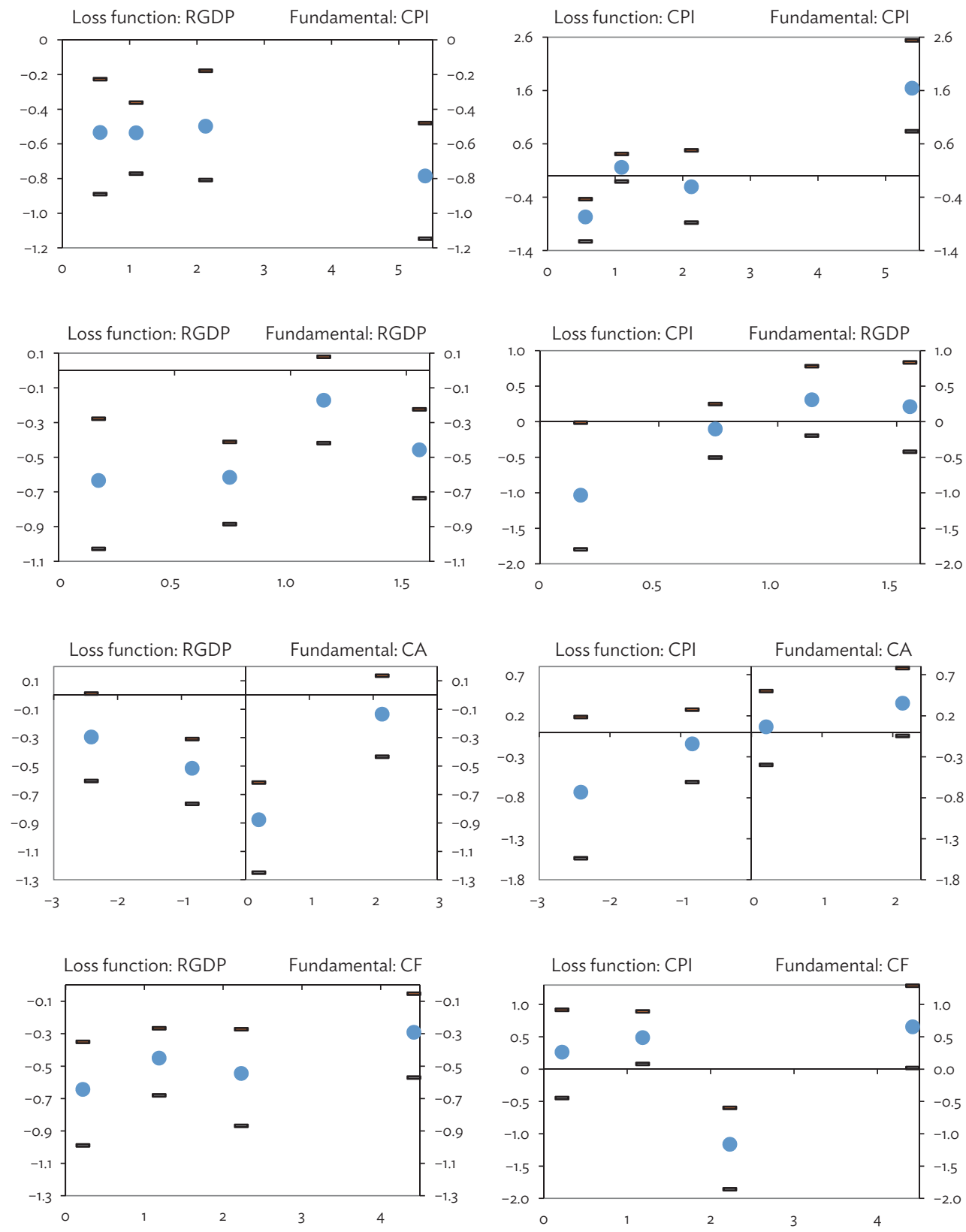
Figure A.1 continued
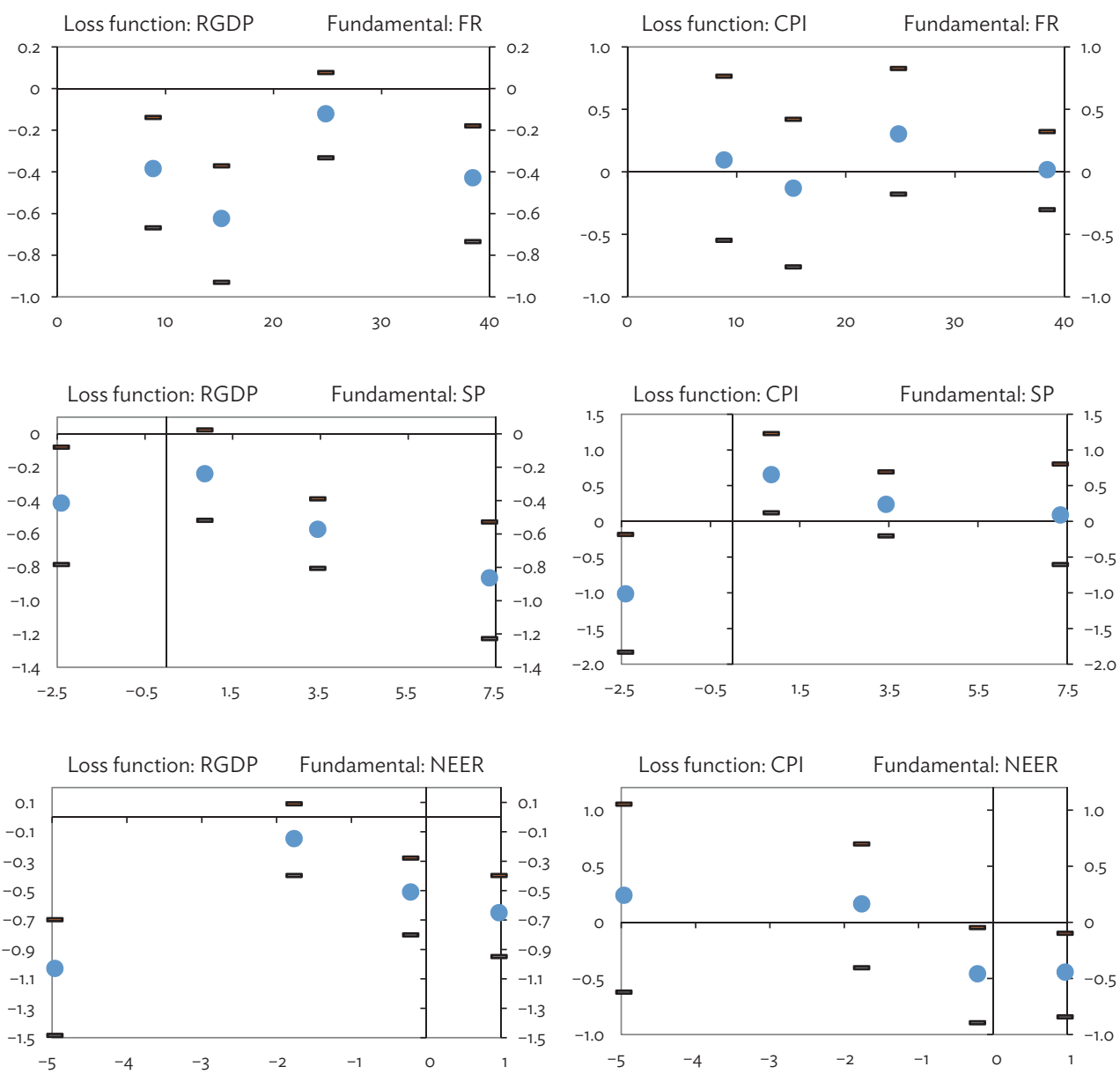

$\mathrm{CA}=$ current account, $\mathrm{CF}=$ capital inflows, $\mathrm{CPI}=$ consumer price index, $\mathrm{FR}=$ foreign reserves, $\mathrm{GDP}=$ gross domestic product, $\mathrm{NEER}=$ nominal effective exchange rate, $\mathrm{RGDP}=$ real gross domestic product, $\mathrm{SP}=$ stock prices, US = United States.

Note: The figure depicts the comprehensive set for Figure 4 with respect to real GDP growth and CPI inflation. Source: Authors' estimates. 
Figure A.2: Fundamentals of Emerging Markets and Nominal Appreciation and Capital Inflows after US Monetary Tightening
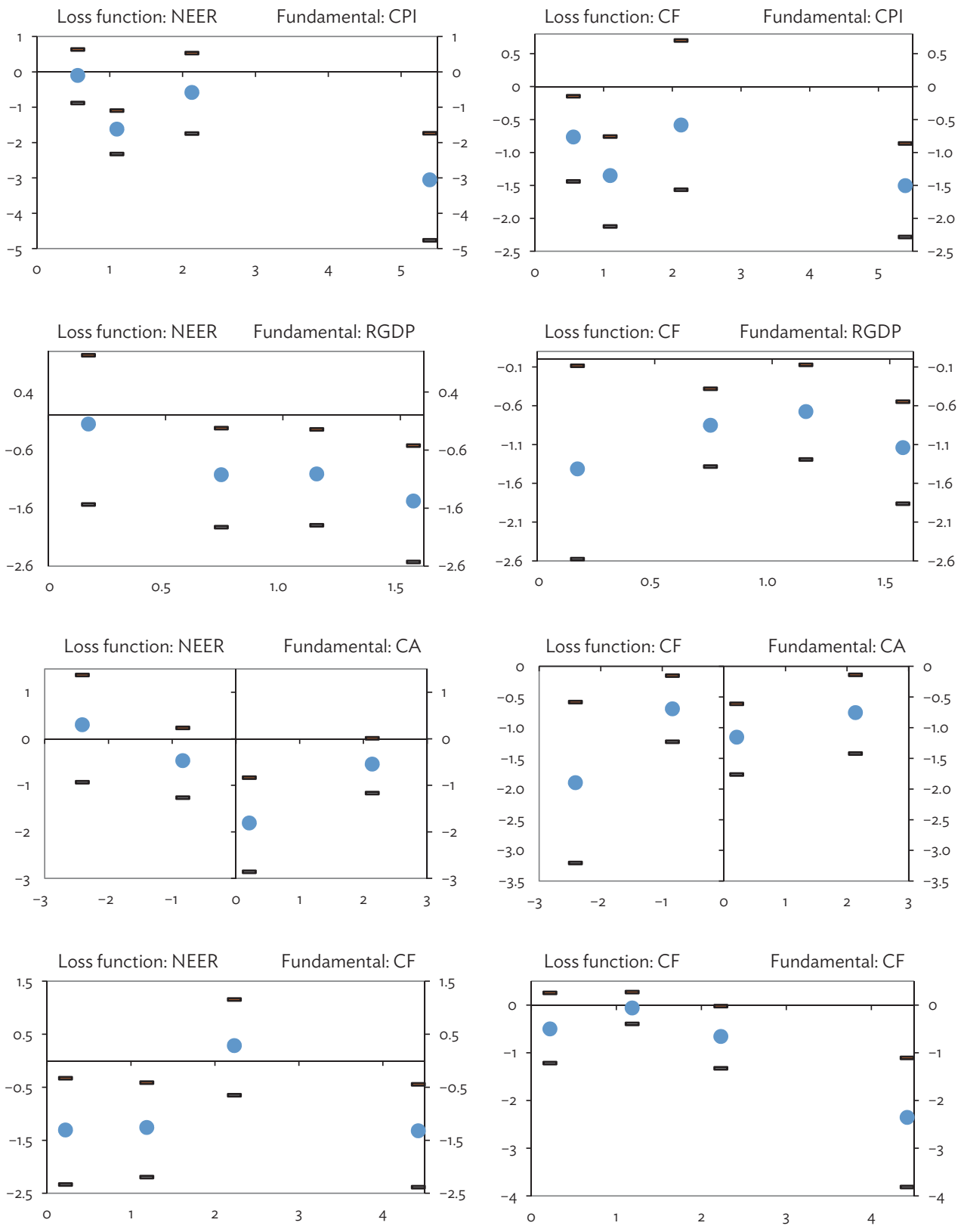
Figure A.2 continued
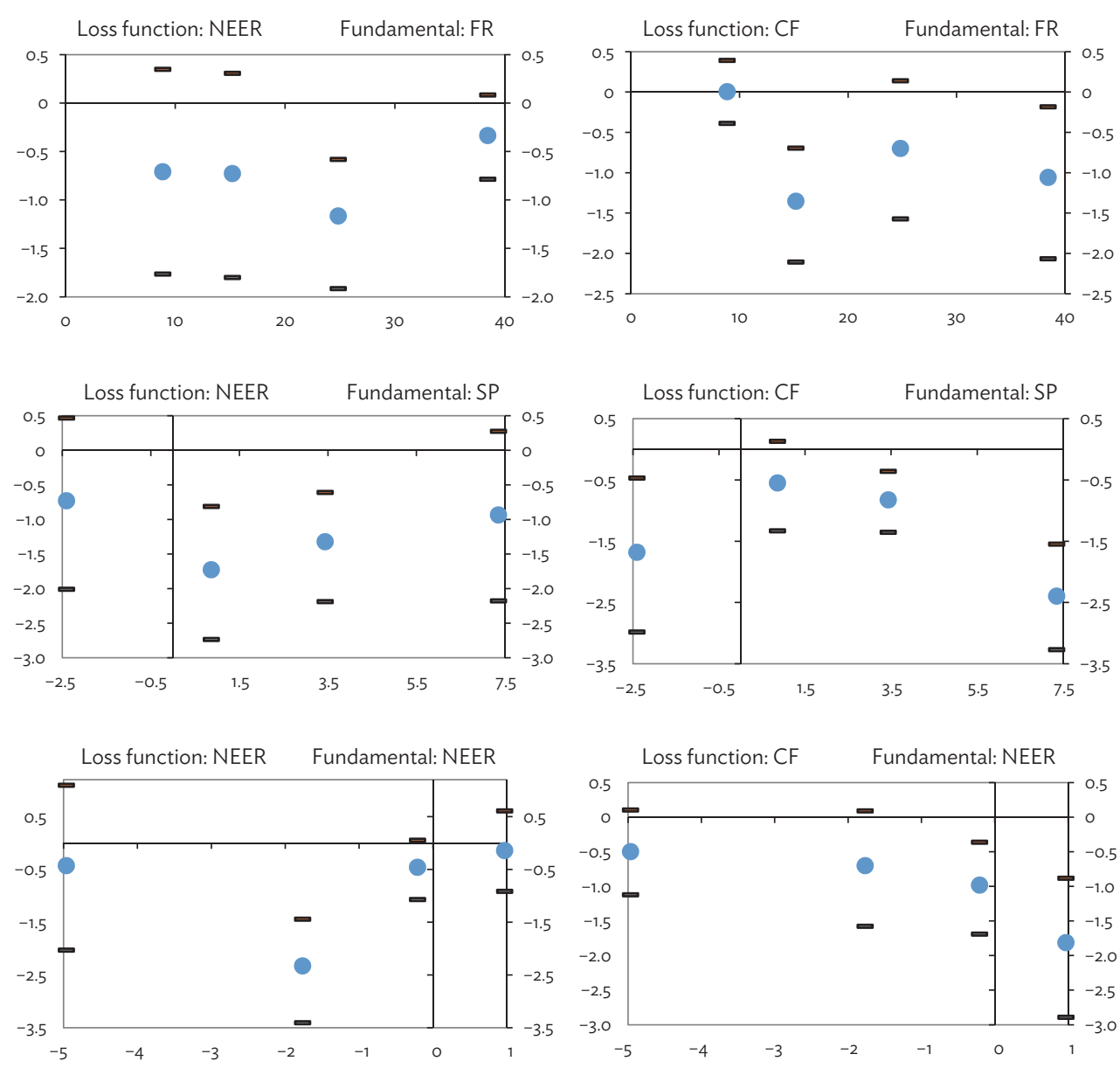

$\mathrm{CA}=$ current account, $\mathrm{CF}=$ capital inflows, $\mathrm{CPI}=$ consumer price index, $\mathrm{FR}=$ foreign reserves, $\mathrm{NEER}=$ nominal effective exchange rate, $\mathrm{RGDP}=$ real gross domestic product, $\mathrm{SP}=$ stock prices, $\mathrm{US}=$ United States.

Note: The figure depicts the comprehensive set for Figure 4 with respect to NEER and CF.

Source: Authors' estimates. 


\section{REFERENCES}

Adolfson, Malin, Stephan Laséen, Jesper Lindé, and Mattias Villani. 2007. "Bayesian Estimation of an Open Economy DSGE Model with Incomplete Pass-through.” Journal of International Economics 72 (2): 481-511.

- 2008. "Evaluating an Estimated New Keynesian Small Open Economy Model." Journal of Economic Dynamics and Control 32 (8): 2690-721.

Alberola, Enrique, Aitor Erce, and José Maria Serena. 2016. "International Reserves and Gross Capital Flows Dynamics.” Journal of International Money and Finance 60: 151-71.

Broner, Fernando, Tatiana Didier, Aitor Erce, and Sergio L. Schmukler. 2013. "Gross Capital Flows: Dynamics and Crises." Journal of Monetary Economics 60 (1): 113-33.

Canova, Fabio. 2005. “The Transmission of US Shocks to Latin America.” Journal of Applied Econometrics 20 (2): 229-51.

Cerutti, Eugenio, Stin Claessens, and Lev Ratnovski. 2014. "Global Liquidity and Drivers of Cross-Border Bank Flows." IMF Working Paper WP/14/69.

Cerutti, Eugenio, Stijn Claessens, and Andrew K. Rose. 2017. "How Important is the Global Financial Cycle? Evidence from Capital Flows.” IMF Working Paper WP/17/193.

Chari, Anusha, Karlye Dilts-Stedman, and Christian Lundblad. 2017. "Taper Tantrums: QE, Its Aftermath, and Emerging Market Capital Flows.” NBER Working Paper No. 23474.

Choi, Woon Gyu, Taesu Kang, Geun-Young Kim, and Byongju Lee. 2017. "Global Liquidity Momenta and EMEs' Policy Responses.” Journal of International Economics 109: 153-66.

Christiano, Lawrence J., Martin Eichenbaum, and Charles L. Evans. 1999. "Monetary Policy Shocks: What Have We Learned and to What End?" In Handbook of Macroeconomics, edited by John B. Taylor and Michael Woodford, 1A, 65-148. Amsterdam: Elsevier.

2005. "Nominal Rigidities and the Dynamic Effects of a Shock to Monetary Policy." Journal of Political Economy 113 (1): 1-45.

Corsetti, Giancarlo, Luca Dedola, and Sylvain Leduc. 2010. "Optimal Monetary Policy in Open Economies." In Handbook of Monetary Economics, edited by Benjamin M. Friedman and Michael Woodford, 3, 861-933. Amsterdam: Elsevier.

Debortoli, Davide, Jinill Kim, Jesper Lindé, and Ricardo Nunes. 2015. “Designing a Simple Loss Function for the Fed: Does the Dual Mandate Make Sense?" Centre for Economic Policy Research Discussion Paper DP10409.

Dées, Stephan, M. Hashem Pesaran, L. Vanessa Smith, and Ron P. Smith. 2010. "Supply, Demand and Monetary Policy Shocks in a Multi-country New Keynesian Model." European Central Bank Working Paper 1239. 
Edwards, Sebastian. 2010. "The International Transmission of Interest Rate Shocks: The Federal Reserve and Emerging Markets in Latin America and Asia." Journal of International Money and Finance 29 (4): 685-703.

2015. "Monetary Policy 'Contagion' in the Pacific: A Historical Inquiry.” Presented at the Federal Reserve Bank of San Francisco Asia Economic Policy Conference, November 19-20.

Farhi, Emmanuel, and Ivan Werning. 2014. "Not Trilemma \& Quest; Capital Controls and Exchange Rates with Volatile Capital Flows." IMF Economic Review 62 (4): 569-605.

Frankel, Jeffrey A., Sergio L. Schmukler, and Luis Servén. 2004. "Global Transmission of Interest Rates: Monetary Independence and Currency Regime." Journal of International Money and Finance 23 (5): 701-33.

Hannan, Edward J., and Barry G. Quinn. 1979. "The Determination of the Order of an Autoregression." Journal of the Royal Statistical Society Series B (Methodological): 190-95.

International Monetary Fund. 2013. "Dancing Together? Spillovers, Common Shocks, and the Role of Financial and Trade Linkages," In World Economic Outlook, October, 3, 81-111. Washington, DC: International Monetary Fund.

Kim, Soyoung, and Hyung Song Shin. 2016. "Offshore EME Bond Issuance and the Transmission Channels of Global Liquidity.” Mimeograph.

Kim, Soyoung, and Doo Yong Yang. 2009. "International Monetary Transmission and Exchange Rate Regimes: Floaters vs. Non-floaters.” ADBI Working Paper Series No. 181.

Lubik, Thomas, and Frank Schorfheide. 2006. "A Bayesian Look at the New Open Economy Macroeconomics," In NBER Macroeconomics Annual 2005, 20, 313-82. Cambridge, MA: MIT Press.

Lustig, Hanno, and Adrien Verdelhan. 2007. "The Cross Section of Foreign Currency Risk Premia and Consumption Growth Risk.” The American Economic Review 97 (1): 89-117.

Miniane, Jacques, and John H. Rogers. 2007. "Capital Controls and the International Transmission of US Money Shocks." Journal of Money, Credit and Banking 39 (5): 1003-35.

Miranda-Agrippino, Silvia, and Hélène Rey. 2015. "World Asset Markets and the Global Financial Cycle." Centre for Economic Policy Research Discussion Paper 10591.

Morgan, Peter J. 2011. "Impact of US Quantitative Easing Policy on Emerging Asia.” Asian Development Bank Institute Workng Paper Series 321.

Rey, Hélène. 2015. "Dilemma not Trilemma: The Global Financial Cycle and Monetary Policy Independence." NBER Working Paper No. 21162.

Romer, Christina D., and David H. Romer. 2004. "A New Measure of Monetary Shocks: Derivation and Implications.” American Economic Review 94 (4): 1055-84. 
Stock, James H., and Mark W. Watson. 2003. "Has the Business Cycle Changed and Why?" In NBER Macroeconomics Annual 2002, 17: 159-230. Cambridge, MA: MIT Press.

Valente, Giorgio. 2009. "International Interest Rates and US Monetary Policy Announcements: Evidence from Hong Kong and Singapore." Journal of International Money and Finance 28 (6): 920-40.

Woodford, Michael. 2003. Interest and Prices: Foundations of a Theory of Monetary Policy. Princeton: Princeton University Press. 


\section{Divergent Emerging Market Economy Responses to Global and Domestic Monetary Policy Shocks}

Building on attempts to gauge the impact policy changes in advanced economies have on emerging economies, this paper investigates how the United States (US) and domestic monetary policy rates affect macroeconomic conditions in emerging market economies (EMEs). Findings indicate that the impact of US policy rate hikes outstrips the effects associated with domestic rate hikes in EMEs. When US monetary policy tightens, bond and equity markets in EMEs are prone to experiencing outflows. Results also show that bond flows are more sensitive to interest rate differentials than are equity flows. It is also found that the magnitude of the effects varies within the group of EMEs, with greater output variations in those EMEs with higher inflation. Consequently, domestic policy alone is not enough to counteract the effects of global policy shocks on capital flows in EMEs.

\section{About the Asian Development Bank}

ADB's vision is an Asia and Pacific region free of poverty. Its mission is to help its developing member countries reduce poverty and improve the quality of life of their people. Despite the region's many successes, it remains home to a large share of the world's poor. ADB is committed to reducing poverty through inclusive economic growth, environmentally sustainable growth, and regional integration.

Based in Manila, ADB is owned by 67 members, including 48 from the region. Its main instruments for helping its developing member countries are policy dialogue, loans, equity investments, guarantees, grants, and technical assistance. 